\title{
An Investigation of the Relationship between Sportsmanship Behavior of Students in Physical Education Course and Their Respect Level
}

\author{
${ }^{1}$ Erzincan University, Erzincan, Turkey \\ ${ }^{2}$ Ministry of Education, İstanbul, Turkey \\ Correspondence: Yakup Koç, Department of Physical Education and Sports, Faculty of Education, Erzincan University, \\ Erzincan, Turkey.
}

Received: June 11, 2017

doi:10.11114/jets.v5i8.2477

\author{
Yakup Koç $^{1}$, Samed Yeniçeri ${ }^{2}$
}

Accepted: June 25, $2017 \quad$ Online Published: July 21, 2017

URL: https://doi.org/10.11114/jets.v5i8.2477

\begin{abstract}
The aim of this study is to examine relationship between the physical education course sportspersonship behaviors and respect levels for high school students. The sample of study consists of randomly selected 505 high school students (215 female and 290 male) attending state schools in the province of İstanbul in 2016-2017 academic year. "Physical Education Course Sportspersonship Behavior Scale", "Respect Scale" and personal information form created by the researcher were used in the study. It was found that the scales was valid and reliable and could be used for high school students. Sportsmanship behaviors significantly differed according to the gender of the students (in favor of the girls), the grade (in favor of 10th grade), school success (in favor of good level) and the type of sports most interested (in favor of physically noncontact sports). It was understood that the scale scores of the students are not significantly different according to the family economic conditions. It was found that physical education course sportspersonship behaviors (Realization of Positive Behavior, Avoidance from Negative Behavior) are significantly related to respect levels (Cosmopolitanism, Communitarianism) positively. And it was seen that the level of respect was a significant predictor of the sportsmanship of the students. It is believed that the implementation of activities aimed at improving the level of respect in schools will be helpful in improving sportsmanship behaviors.
\end{abstract}

Keywords: physical education course, sportsmanship behavior, respect level

\section{Introduction}

The increase in non-fair play events and violence in sport environments has increased the importance of sportsmanship training in schools. Of course, all individuals live their sporting environment primarily with physical education courses. Trainings to be given during this period will contribute to the awareness of future athletes, coaches, spectators and other elements. Already the beginning of sportsmanship practices is based on similar reasons in England (Yildiran, 2005). The concept of sportsmanship (sportspersonship) which is used to express the ideals of morality in sports is defined in various ways from different perspectives. In general, sportsmanship refers to virtues such as justice, self-control, courage, and persistence (Shields \& Bredemeier, 1995), and has been associated with interpersonal concepts of treating others and being treated fairly, maintaining self-control in dealing with others, and respect for both authority and opponents. When we look at the literature, there are researches that examine the relationship of sportsmanship with personality traits such as empathy (Balçıanlı \& Yıldıran, 2011; Koç, 2017b), violence (Koç, 2017b), aggression (Koç \& Güllü, 2017), and patience (Koç, 2017a). In these researches sportsmanship was found to be closely related to these personality traits. The better the understanding of sportsmanship, the more effective sportsmanship development programs will be in schools and sports fields. In this respect, sportsmanship should be dealt with in all aspects and number of conceptual studies should be increased. When we look at the definition of sportsmanship, it is seen that sportsmanship is also related to the individual's respectful nature. Vallerand and his colleagues described the four dimensions of sportsmanship as "respect" in the sportsmanship orientation scale they developed (Vallerand, Briere, Blanchard, \& Provencher, 1997).

Dictionaries typically provide several alternate definitions of respect (Hendrick, Hendrick, \& Zacchilli, 2011). Respect is an important aspect of human relating, both in intimate, personal relationships and in more formal role relationships, where respect is part of interpersonal civility. Respect is not just one of the core value, it is also the basis of many values 
(Loomans \& Loomans, 2005). Respect is one of the basic characteristics that a good person should have. Respect is that when one should know the boundary between own's personality and another's personality and does not cross that boundary and should take care of someone else's rights, even if he is against him (Demircan, 2017). Although respect is a fundamental value that plays a central role in human relationships and in the various forms of human life in general, it is a neglected topic in academic studies (Yazıc \& Yazıc1, 2015). In the philosophy of ethics, especially Kant, and the philosophers who followed him, did some theoretical work for they paid particular attention to respect (Türk, 2009). There are some works that theoretically examine the respect in the literature. Darwall (1977), based on many scholars, argues that there are two kinds of respect. The first is the recognition respect and the second is the appraisal respect. Recognition respect does not respecting persons by any property or difference in others, but respecting that they are merely persons. This respect is based on the principle that everyone is equal. Appraisal respect is the result of the evaluation of a person's positive qualities. In Langdon's (2007) study of qualitative and quantitative methods, he found that the concept of respect came from four dimensions, social rules, equality, caring and social power. Simon (2007) distinguished between two types of respect: vertical respect and horizontal respect. Horizontal respect means equality or mutuality within a group of people, whereas vertical respect means difference on some defined status dimension. For most of recorded history, humans were organized vertically, with masses of people at the bottom and a small group of ruling elite at the top. This view of social life is very common, because even the organizing religions are formed in this way. Yazıc1 and Yazıc1, (2015) have considered the respect in two dimensions as theoretically cosmopolitan and communitarian approaches. Despite the universal value understanding of the cosmopolitan paradigm, locality is a matter of communitarian value. As demonstrated by theoretical and practical work, respect is both a universal value and a culturally formed and sustained value (Finkelstein, 2008). Cosmopolitan and communitarian ways of thinking have been two approaches in the last thirty years in the literature of ethic and political philosophy. Advocating the universal way of thinking, freedom of expression, adopting equality between all kinds of people, is not a party to the punishment. It attaches importance to the democratic and egalitarian conception of life. On the other hand, the local way of thinking gives importance to searching for the salvation of people and their remedies within their own society (Türk, 2009). Loomans \& Loomans (2005) emphasized the importance of family and school in respect education. Research has shown that respect is related to self-esteem (Ellemers, Doosje, \& Spears, 2004), reaction to authority (Tyler \& Lind, 1992), group identity (Jetten, Schmitt, Branscombe, \& McKimmie, 2005), gender (Jackson, Esses, \& Burris, 2001), love in romantic relation (Hendrick, Hendrick, \& Zacchilli, 2011), communication (Mc Cann, Dailey, Giles, \& Ota, 2005) and social justice (DeCremer \& Tyler, 2005),

Activities oriented to improving sportsmanship behaviors of students are expected be implemented by means of physical education courses in schools. At this point, which personality traits are related to sportsmanship behaviors is important. Within this context, respect levels of high school students are considered to be related to their sportsmanship behaviors. Indeed, in the official campaign of the FIFA, the concept of fair play and respect were used together (www.fifa.com). But in sportsmanship and fair-play works, there is no study that directly examines the relationship between sportsmanship and respect. Therefore, it is thought that the examination of the level of relationship between sportsmanship and respect is needed. The aim of this study is to examine relationship between the physical education course sportsmanship behaviors and respect levels for high school students.

\section{Method}

\subsection{Research Model}

The survey model was used in this research. The survey model is a research approach aiming to describe the case existing now or how it existed in the past. The individual or object that is subject to research as well as how they were attempted to be defined in their circumstances. No effort was shown to affect or change them in any way (Karasar, 2003).

\subsection{The Study Group}

The sample of study involves a total of 505 students (215 female, 290 male) from public high schools within the İstanbul province who were selected randomly in 2016-2017 academic year. Required permissions were obtained from the Ministry of National Education.

\subsection{Research Instruments}

\subsubsection{Physical Education Course Sportspersonship Behavior Scale (PECSBS)}

(PECSBS) developed by Koç (2013) consists of 22 items and two subscales. The first subscale consisting of 11 items is related to the "Realization of Positive Behavior (RPB)" while the second subscale composed of 11 items concerns "Avoidance from Negative Behavior (ANB)". PECSBS was scored on a 5-point Likert scale with "never" (1) and "always" (5) serving as end points. ANB subscale items were reverse scored. The total score obtained in the scale was 
assessed as "Total Sportsmanship Behavior (TSB)". RPB subscale can be exemplified by the item "I apologize from my opponent when I get nervous and break the rules of the game during the physical education course" and ANB subscale can be exemplified by the item "I make fun of the members of the rival team whenever I win against them during the physical education course".

\subsubsection{Respect Scale}

"Respect Scale" developed by Yazıc1 \& Yazicı (2015) consists of 17 items and two subscales. The first subscale consisting of 9 items is related "cosmopolitan respect" while the second subscale composed of 8 items concerns "communitarian respect". Cosmopolitan respect subscale can be exemplified by the item "Man is worth more than everything" and communitarian respect subscale can be exemplified by the item "Those who value each other respect each other". Scale was scored on a 5-point Likert scale.

\subsubsection{Personal Information Form}

The form created by the researcher was used in the study. The form includes features of students such as their grade, gender, success level of school, family economic status and the type of sports they are interested in most. The types of sports they are interested in are mostly grouped as team sports played with ball (like football, handball, etc.) and physically non-contact sports (like volleyball, badminton, etc.).

\subsection{Data Analysis}

Reliability and validity tests of the scales were done. The scores the students obtained in the scales were reexamined in accordance with independent variables. Besides, the relationship between the values of scales and simple linear regression was tested. The obtained data were checked for parametric analysis or non-parametric analysis (kurtosis, skewness, scatter and histogram graph). In addition, the equality of group variances is examined (Levene $\mathrm{F}$ test). ANOVA, $t$ test, Tukey and Pearson Correlation tests were applied to parametric analyzes of normal distribution. For the assessment of the data, SPSS 15 and LISREL 8,7 programs were employed.

\section{Results}

At the end of the EFA analyses of the "PECSBS", results showed that two-factor structure of the scale was emerged in its original form. Results of the confirmatory factor analysis (CFA) of PECSBS suggested the following values: $\chi^{2} / \mathrm{df}=$ 2.23, RMSEA=.051, CFI=.97, GFI=.92 and NNFI=.96. As a result of CFA which was conducted to test the factor structure, consistency values were found to be admissible. No items were excluded. Reliability of Cronbach Alpha internal consistency of the scale (TSB) was determined as $\alpha=.87$. In terms of subscale, RPB was determined as $\alpha=.82$ and for ANB value was determined as $\alpha=.87$. It was found that the scale was valid, reliable and it could be used.

Since Respect Scale was developed by undergraduate students, 20 high school students were pre-applied in order to use the scale in high school students. The idea that preliminary results are appropriate for high school students has also emerged. In addition, after the positive opinion of a qualified lecturer in psychology guidance was taken, the scale was used in the study. And factor analysis was conducted for high school students. In the explanatory factor analysis (EFA) of respect scale for high school students $(\mathrm{n}=505), \mathrm{KMO}$ value was found .89 and Bartlett test was significant $(\mathrm{p}<.000)$. Total variance both factors (9-item "Cosmopolitan Respect" factor and 8-item "Communitarian Respect" factor) accounted for was found to be $42.57 \%$. Item-total correlation values ranged between .30 and .57 . To test the factor structure obtained through EFA, the results of CFA suggested the following values X2/sd=2.63, RMSEA=.058, GFI $=.93$, NNFI $=.96, \mathrm{CFI}=.96$ and $\mathrm{AGFI}=.91$. As a result of confirmatory factor analysis in order to test factor structure, consistency values were found to be admissible. No items were excluded. The score obtained from the sum of the scale was evaluated as "Total Respect (TS)" Reliability of Cronbach Alpha internal consistency of the scale (TR) was determined as $\alpha=.85$. In terms of subscale Cosmopolitan Respect value was determined as $\alpha=.84$ and for Communitarian Respect was determined as $\alpha=.78$. It was found that the scale was valid and reliable and could be used for high school students.

\subsection{Grade}

Significant differences were found in physical education course sportsmanship behaviors (ANB, RPB, and TSB), and respect level (Cosmopolitan, Communitarian) in terms of grades $(p<0.01)$. The paired comparison by Tukey test showed that 10th grade students have significantly higher levels of sportsmanship and respect level than 9th and 11th grade students (Table 1). 
Table 1. The comparison of students' average scores of scales in terms of their grade levels (One-Way Anova)

\begin{tabular}{|c|c|c|c|c|c|c|c|}
\hline Factor & Grade & $\mathbf{N}$ & $\mathbf{X}$ & Sd & $\mathbf{F}$ & $p$ & Tukey T. \\
\hline \multirow{3}{*}{ Realization of Positive Behavior } & 9 & 208 & 3.67 & .80 & 6.71 & .001 & $*(10>9)$ \\
\hline & 10 & 175 & 3.92 & .77 & & & $*(10>11)$ \\
\hline & 11 & 122 & 3.63 & .78 & & & \\
\hline \multirow{3}{*}{ Avoidance from Negative Behavior } & 9 & 208 & 3.76 & .98 & 16.25 & .000 & $*(10>9)$ \\
\hline & 10 & 175 & 4.21 & .65 & & & $*(10>11)$ \\
\hline & 11 & 122 & 3.76 & .81 & & & \\
\hline \multirow{3}{*}{ Total Sportsmanship Behavior } & 9 & 208 & 3.72 & .72 & 17.31 & .000 & $*(10>9)$ \\
\hline & 10 & 175 & 4.07 & .62 & & & $*(10>11)$ \\
\hline & 11 & 122 & 3.69 & .62 & & & \\
\hline \multirow{3}{*}{ Cosmopolitan Respect } & 9 & 208 & 3.80 & .80 & 5.90 & .003 & $*(10>9)$ \\
\hline & 10 & 175 & 4.07 & .73 & & & \\
\hline & 11 & 122 & 3.93 & .70 & & & \\
\hline \multirow{3}{*}{ Communitarian Respect } & 9 & 208 & 3.74 & .73 & 6.13 & .002 & $*(10>9)$ \\
\hline & 10 & 175 & 3.94 & .67 & & & $*(10>11)$ \\
\hline & 11 & 122 & 3.67 & .83 & & & \\
\hline \multirow{3}{*}{ Total Respect } & 9 & 208 & 3.77 & .67 & 7.52 & .001 & $*(10>9)$ \\
\hline & 10 & 175 & 4.00 & .57 & & & $*(10>11)$ \\
\hline & 11 & 122 & 3.80 & .64 & & & \\
\hline
\end{tabular}

$* \mathrm{p}<0.05$

\subsection{Gender}

Table 2. The comparison of students' average scores of scales in terms of their gender (t-Test)

\begin{tabular}{|c|c|c|c|c|c|c|}
\hline Factor & Gender & $\mathbf{N}$ & $\mathbf{X}$ & sd & $\mathbf{t}$ & $p$ \\
\hline \multirow{2}{*}{ Realization of Positive Behavior } & Female & 215 & 3.89 & .76 & \multirow{2}{*}{3.56} & \multirow{2}{*}{$.000 * *$} \\
\hline & Male & 290 & 3.64 & .80 & & \\
\hline \multirow{2}{*}{ Avoidance from Negative Behavior } & Female & 215 & 4.10 & .86 & \multirow{2}{*}{4.26} & \multirow{2}{*}{$.000 * *$} \\
\hline & Male & 290 & 3.77 & .84 & & \\
\hline \multirow{2}{*}{ Total Sportsmanship Behavior } & Female & 215 & 4.00 & .68 & \multirow{2}{*}{4.71} & \multirow{2}{*}{$.000 * *$} \\
\hline & Male & 290 & 3.71 & .66 & & \\
\hline \multirow{2}{*}{ Cosmopolitan Respect } & Female & 215 & 4.04 & .70 & \multirow{2}{*}{3.06} & \multirow{2}{*}{$.002 * *$} \\
\hline & Male & 290 & 3.83 & .79 & & \\
\hline \multirow{2}{*}{ Communitarian Respect } & Female & 215 & 3.82 & .76 & \multirow{2}{*}{.82} & \multirow{2}{*}{.413} \\
\hline & Male & 290 & 3.77 & .73 & & \\
\hline \multirow{2}{*}{ Total Respect } & Female & 215 & 3.93 & .61 & \multirow{2}{*}{2.31} & \multirow{2}{*}{$.022 *$} \\
\hline & Male & 290 & 3.80 & .65 & & \\
\hline
\end{tabular}

$* \mathrm{p}<0.05 \quad * * \mathrm{p}<0.01$

Significant differences were determined in physical education course sportsmanship behaviors, and respect level (except for communitarian respect) in terms of gender $(p<0.05)$. The results also showed that females have higher sportsmanship behavior and respect level than their male counter parts. There was no effect of gender in the points obtained by the students from the Communitarian respect factor $(p>0.05)$ (Table 2).

\subsection{Success Level of School}

Significant differences were determined in physical education course sportsmanship behaviors, and respect level (except for communitarian respect) in terms of success level of school $(p<0.05)$. It was understood that students with good school achievement had significantly higher levels of sportsmanship and respect than those with a weak and moderate (Table 3). 
Table 3. The comparison of students' average scores of scales in terms of their success level of school (One-Way Anova)

\begin{tabular}{|c|c|c|c|c|c|c|c|}
\hline Factor & Group & $\mathbf{N}$ & $\mathbf{X}$ & Sd & $\mathbf{F}$ & $p$ & Tukey T. \\
\hline \multirow{3}{*}{ Realization of Positive Behavior } & Weak (W) & 144 & 3.52 & .83 & 13.98 & .000 & $*(\mathrm{G}>\mathrm{W})$ \\
\hline & Moderate $(\mathrm{M})$ & 222 & 3.73 & .82 & & & $*(\mathrm{G}>\mathrm{M})$ \\
\hline & Good $(\mathrm{G})$ & 139 & 4.01 & .64 & & & $*(\mathrm{M}>\mathrm{W})$ \\
\hline \multirow{3}{*}{ Avoidance from Negative Behavior } & Weak & 144 & 3.82 & .84 & 4.58 & .011 & $*(\mathrm{G}>\mathrm{W})$ \\
\hline & Moderate & 222 & 3.86 & .91 & & & $*(\mathrm{G}>\mathrm{M})$ \\
\hline & Good & 139 & 4.10 & .78 & & & \\
\hline \multirow{3}{*}{ Total Sportsmanship Behavior } & Weak & 144 & 3.68 & .68 & 11.61 & .000 & $*(\mathrm{G}>\mathrm{W})$ \\
\hline & Moderate & 222 & 3.80 & .70 & & & $*(\mathrm{G}>\mathrm{M})$ \\
\hline & Good & 139 & 4.05 & .61 & & & \\
\hline \multirow{3}{*}{ Cosmopolitan Respect } & Weak & 144 & 3.90 & .74 & 9.27 & .000 & $*(\mathrm{G}>\mathrm{W})$ \\
\hline & Moderate & 222 & 3.81 & .78 & & & $*(\mathrm{G}>\mathrm{M})$ \\
\hline & Good & 139 & 4.15 & .70 & & & \\
\hline \multirow{3}{*}{ Communitarian Respect } & Weak & 144 & 3.89 & .71 & 1.92 & .147 & \\
\hline & Moderate & 222 & 3.73 & .74 & & & \\
\hline & Good & 139 & 3.79 & .78 & & & \\
\hline \multirow{3}{*}{ Total Respect } & Weak & 144 & 3.89 & .62 & 4.50 & .012 & $*(\mathrm{G}>\mathrm{M})$ \\
\hline & Moderate & 222 & 3.77 & .66 & & & \\
\hline & Good & 139 & 3.97 & .59 & & & \\
\hline
\end{tabular}

$* p<0.05$

\subsection{Family Economic Status}

Table 4. The comparison of students' average scores of scales in terms of their family economic status (One-WayAnova)

\begin{tabular}{lllllll}
\hline Factor & Group & N & X & Sd & F & p \\
\hline \multirow{3}{*}{ Realization of Positive Behavior } & Weak & 66 & 3.66 & .77 & .47 & .625 \\
& Moderate & 339 & 3.76 & .79 & & \\
& Good & 100 & 3.77 & .83 & & \\
& Weak & 66 & 3.88 & .83 & .08 & .927 \\
& Moderate & 339 & 3.91 & .87 & & \\
Total Sportsmance from Negative Behavior & Good & 100 & 3.93 & .87 & & \\
& Weak & 66 & 3.77 & .65 & .35 & .704 \\
& Moderate & 339 & 3.84 & .70 & & \\
Cosmopolitan Respect & Good & 100 & 3.85 & .67 & & \\
& Weak & 66 & 3.90 & .80 & .37 & .692 \\
Communitarian Respect & Moderate & 339 & 3.91 & .77 & & \\
& Good & 100 & 3.98 & .71 & & \\
& Weak & 66 & 3.77 & .69 & .08 & .927 \\
& Moderate & 339 & 3.80 & .76 & & \\
Total Respect & Good & 100 & 3.77 & .72 & & \\
& Weak & 66 & 3.84 & .61 & .08 & .922 \\
\hline
\end{tabular}

No statistically significant differences were determined in physical education course sportsmanship behaviors, and respect level in terms of their family economic status $(p>.05)$ (Table 4$)$. 


\subsection{Type of Sports}

Table 5: The comparison of students' average scores of scales in terms of their type of sports they are interested in most (t-Test)

\begin{tabular}{lllllll}
\hline Factor & Group $^{\mathbf{a}}$ & $\mathbf{N}$ & $\mathbf{X}$ & sd & $\mathbf{t}$ & $\boldsymbol{p}$ \\
\hline \multirow{2}{*}{ Realization of Positive Behavior } & 1 & 294 & 3.64 & .82 & -3.67 & $.000^{* *}$ \\
\multirow{2}{*}{ Avoidance from Negative Behavior } & 2 & 211 & 3.90 & .74 & & \\
\multirow{2}{*}{ Total Sportsmanship Behavior } & 1 & 294 & 3.78 & .84 & -4.02 & $.000^{* *}$ \\
\multirow{2}{*}{ Cosmopolitan Respect } & 2 & 211 & 4.09 & .86 & & \\
& 1 & 294 & 3.72 & .67 & -4.63 & $.000^{* *}$ \\
Communitarian Respect & 2 & 211 & 4.00 & .67 & & \\
Total Respect & 1 & 294 & 3.84 & .79 & -2.96 & $.003 * *$ \\
& 1 & 211 & 4.04 & .70 & & \\
& 2 & 294 & 3.74 & .72 & -1.69 & .091 \\
\hline
\end{tabular}

$* * p<0.01\left({ }^{a}: 1=\right.$ team sports played with ball, $2=$ physically non-contact sports)

Significant differences were determined in physical education course sportsmanship behaviors, and respect level (except for communitarian) in terms of type of sports they are interested in most $(p<0.01)$. Students which were interested in physically non-contact sports showed more sportsmanship behaviors and respect level compared to students that are interested in team sports played with ball (Table 5).

\subsection{Relationships between Sportspersonship Behaviors and Respect Levels}

Table 6. Relationships of the physical education course sportsmanship behaviors with respect level (Pearson)

\begin{tabular}{|c|c|c|c|c|c|c|c|}
\hline & Factor & 1 & 2 & 3 & 4 & 5 & 6 \\
\hline \multirow{8}{*}{$\begin{array}{l}\stackrel{n}{o} \\
\text { II } \\
z\end{array}$} & 1. Realization of Positive Behavior & - & $.36 * *$ & $.81 * *$ & $.34 * *$ & $.17 * *$ & $.30 * *$ \\
\hline & 2. Avoidance from Negative Behavior & & - & $.84 * *$ & $.25 * *$ & $.11 *$ & $.22 * *$ \\
\hline & 3. Total Sportsmanship Behavior & & & - & $.35^{* *}$ & $.17 * *$ & $.31 * *$ \\
\hline & 4. Cosmopolitan Respect & & & & - & $.43 * *$ & $.85^{* *}$ \\
\hline & 5. Communitarian Respect & & & & & - & $.84 * *$ \\
\hline & 6. Total Respect & & & & & & - \\
\hline & M (1-5) & 3.75 & 3.91 & 3.83 & 3.92 & 3.79 & 3.86 \\
\hline & SD & .80 & .86 & .68 & .76 & .74 & .64 \\
\hline
\end{tabular}

$* \quad p<0.05 \quad * * p<0.01$

Total sportsmanship behaviors of the students were shown to display positive moderate significant relationship with their total respect levels $(\mathrm{r}=.31 ; \mathrm{p}<0.01)$. Moreover, it was noticed that the highest relationship was between total sportsmanship behavior and cosmopolitan respect $(\mathrm{r}=.35$; $\mathrm{p}<0.01)$ (Table 6). This means that as respect increases, sportsmanship also increases.

\subsection{Regression Analysis}

Table 7. Summary of simple regression analysis for students' sportsmanship scores $(\mathrm{N}=505)$

\begin{tabular}{lllllll}
\hline Realization of Positive Behavior & $\mathrm{B}$ & $\mathrm{SE}(\mathrm{B})$ & $\beta$ & $t$ & $p$ & $\mathrm{R}^{2}$ \\
\hline Cosmopolitan Respect & .355 & .044 & .338 & 8.055 & $.000^{* *}$ & .114 \\
Communitarian Respect & .180 & .047 & .168 & 3.833 & $.000^{* *}$ & .028 \\
Total Respect & .376 & .053 & .300 & 7.065 & $.000^{* *}$ & .090 \\
\hline Avoidance from Negative Behavior & $\mathrm{B}$ & $\mathrm{SE}(\mathrm{B})$ & $\beta$ & $t$ & $p$ & $\mathrm{R}^{2}$ \\
\hline Cosmopolitan Respect & .287 & .049 & .252 & .5 .848 & $.000^{* *}$ & .064 \\
Communitarian Respect & .128 & .051 & .110 & 2.483 & $.000^{* *}$ & .012 \\
Total Respect & .292 & .059 & .215 & 4.939 & $.000^{* *}$ & .046 \\
\hline Total Sportsmanship Behavior & $\mathrm{B}$ & $\mathrm{SE}(\mathrm{B})$ & $\beta$ & $t$ & $p$ & $\mathrm{R}^{2}$ \\
\hline Cosmopolitan Respect & .317 & .038 & .352 & 8.430 & $.000^{* *}$ & .124 \\
Communitarian Respect & .153 & .040 & .166 & 3.770 & $.000^{* *}$ & .027 \\
Total Respect & .331 & .046 & .307 & 7.238 & $.000^{* *}$ & .094 \\
\hline
\end{tabular}

$* * p<0.01$

A simple linear regression was calculated to predict sportsmanship based on respect. As a result of the analysis, total respect level was noticed to be significantly predicting the total sportsmanship behavior $\left(\mathrm{R}^{2}=.09, p<.01\right)$ (Table 7). For subscales, cosmopolitan respect level was noticed to be significantly predicting the total sportsmanship behavior 
$\left(\mathrm{R}^{2}=.12, p<.01\right)$ and communitarian respect level was noticed to be significantly predicting the total sportsmanship behavior $\left(\mathrm{R}^{2}=.03, p<.01\right)$. Especially the positive effect of the cosmopolitan respect seems to be an important predictor of sportsmansip behavior.

\section{Discussion and Conclusion}

In this study, it was carried out that the scores the students obtained in the scales were examined in accordance with independent variables and the relationship between the values of scales was tested. And finally, it was calculated regression analysis for students' sportsmanship scores

The research results showed a significant differences in physical education course sportsmanship behaviors, and respect level in terms of grades. 10th grade students have significantly higher levels of sportsmanship and respect level than 9th and 11th grade students. In studies that used the same scale displayed a significantly decreasing sportsmanship level for students with higher grades (Esentürk, İlhan, \& Çelik 2015; Koç \& Tamer, 2016; Koç, 2017b). Tsai and Fung (2005) found that older students think less sportsmanship than younger ones. Besides, young female students think the highest level of importance to sportsmanship. But, Shields, La Voi, Bredemeier and Power (2007) did not find any a significant difference in the sportsmanship behaviors of grade 5 to 8 students. However, the level of sportsmanship decreased as the class increased. In the literature search, no study was found on the differentiation of the level of respect in terms of grade level. It is thought that as the age progresses, the negative environment reduces the sportsmanship. Undoubtedly, improving sportsmanship attitudes in the school settings will prevent the decline of sportsmanship. As a matter of fact, it is possible to see settings on sportsmanship and respect in high school programs in USA (www.northropbruins.org; www.hb.edu).

The research results also revealed that significant differences were determined in physical education course sportsmanship behaviors, and respect level (except for communitarian respect) in terms of gender. The results showed that females have higher sportsmanship behavior and respect level than their male counter parts. There was no effect of gender in the points obtained by the students from the Communitarian respect factor. Only a few numbers of studies is present investigating the effect of gender on sportsmanship. In their study, Esentürk, et al. (2015) found a significantly higher level of sportsmanship behaviors for female students compared to males. Also, Topan (2011) stated that females show sportsmanship behaviors in a more sensibly way compared to males in winning and losing conditions. A study by Tsai and Fung (2005) on sportsmanship orientation of high school basketball and volleyball students exhibited that young female students attach the highest level of importance to sportsmanship, yet some other contrariwise studies are present. A significant difference in sportsmanship behaviors by grade could not be found neither by Miller, Roberts and Ommundsen (2004) among competing young football players nor by Shields et al. (2007) among grade 5-8 students. A literature review did not return any study on differentiation of respect level by gender.

It was found significant differences in physical education course sportsmanship behaviors, and respect level (except for communitarian respect) in terms of success level of school. It was understood that students with good school achievement had significantly higher levels of sportsmanship and respect than those with a weak and moderate. In the study conducted by Koç \& Güllü, (2017) there was no significant difference in the sportsmanship behaviors according to the school achievement status of the students. It is suggested to study this variable so that this can be studied more thoroughly.

No statistically significant differences were determined in physical education course sportsmanship behaviors, and respect level in terms of their family economic status. According to the study conducted by Koç \& Güllü, (2017) family's economic status was no significant differences in the behavior of sportsmanship too. A literature review did not return any study on differentiation of respect level by family's economic status

Significant differences were determined in physical education course sportsmanship behaviors and respect level (except for communitarian) in terms of type of sports they are interested in most. Students which were interested in physically non-contact sports showed more sportsmanship behaviors and respect level compared to students that are interested in team sports played with ball. A literature review supported the findings of this study in that sportsmanship has been differentiated for students and athletes according to branch and type of sports they engage in. Indeed, studies show that sportsmanship behaviors of high school students interested in team sports without physical non-contact are better compared to those engaged in other sports branches (Koç \& Güllü, 2017; Koç, 2017b), and sportsmanship values of high school students interested in volleyball (physically non-contact sports) are significantly better than those interested in football (team sports played with ball) (Esentürk, et al. 2015).

It was found a positive moderate significant relationship between total sportsmanship behaviors of the students with their total respect levels. Moreover, it is understood that universal respect values are more important than communiterian respect values for sportsmanship when the higher relationship is evaluated between total sportsmanship behavior and Cosmopolitan respect. In the literature researches, no studies investigating the relationship between 
sportsmanship behaviors and respect levels were found.

It was seen that the level of respect was a significant predictor of the sportsmanship of the students. Especially, the positive effect of the cosmopolitan respect that advocating the universal way of thinking (Türk, 2009) seems to be an important predictor of sportsmansip behavior. From these results we can see that your sportsmanship has universal values. However, the study results were as expected. More supporting studies are required to reveal the degree of positive relationship between the findings more clearly. New studies on this subject are recommended.

Within the context of the study it was found that the scales was valid and reliable and could be used for high school students. Sportsmanship behaviors significantly differed according to the gender of the students (in favor of the girls), the grade (in favor of 10th grade), success level of school (in favor of good level) and the type of sports most interested (in favor of physically noncontact sports). And it was understood that the scale scores of the students are not significantly different according to the family economic status.

When research findings were evaluated in general, it was found that physical education course sportsmanship behaviors are significantly related to respect levels positively and level of respect was a significant predictor of the sportsmanship of the students. It is believed that the implementation of activities aimed at improving the level of respect in schools will be helpful in improving sportsmanship behaviors. It is suggested to work in different types of groups on the grounds of the lack of studies that show the level of relationship between sportsmanship behaviors and the level of respect.

\section{References}

Balçıkanl, S. G., \& Yıldıran, İ. (2011). Profesyonel futbolcular sportmenlik yönelimleri ve empatik eğilim düzeyleri. Beden Eğitimi ve Spor Bilimleri Dergisi, IX(2), 49-56.

Darwall, S. L. (1977). “Two Kinds of Respect”, Ethics, 88(1), 36-49. https://doi.org/10.1086/292054

DeCremer, D., \& Tyler, T. (2005). Am I respected or not? Inclusion and reputation as issues in group membership. Social Justice Research, 18, 121-153. https://doi.org/10.1007/s11211-005-7366-3

Demircan, Ş. (2017). Çocuklarda sayg1 eğitimi, $\quad$ Retrieved 31.05 .2017 from http://www.mirathaber.com/seyma-demircan-cocuklarda-saygi-egitimi-20-373y.html

Ellemers, N., Doosje, B., \& Spears, R. (2004). Sources of respect: The effects of being liked by ingroups and outgroups. European Journal of Social Psychology, 34, 155-172. https://doi.org/10.1002/ejsp.196

Esentürk, O. K., İlhan, E. L., \& Çelik, O. B. (2015). Examination of high school students' sportsmanlike conducts in physical education lessons according to some variability. Science, Movement and Health, 15(2, Supplement), 627-634.

Finkelstein, E. (2008). Toward an anthropology of respect. Social Analysis, 53(3), 99-117. https://doi.org/10.3167/sa.2008.520305

Hendrick, C. Hendrick, S. S., \& Zacchilli, T. L. (2011). Respect and Love in Romantic Relationships, Acta De Investıgación Psicológıca, 1(2), 316-329.

Jackson, L. M., Esses, V. M., \& Burris, C. T. (2001). Contemporary sexism and discrimination: The importance of respect for men and women. Personality and Social Psychology Bulletin, 27, 48-61. https://doi.org/10.1177/0146167201271005

Jetten, J., Schmitt, M., Branscombe, N., \& McKimmie, B. (2005). Suppressing the negative effect of devaluation on group identification. Journal of Experimental Social Psychology, 41, 208-215. https://doi.org/10.1016/j.jesp.2004.07.008

Karasar, N. (2003). Scientific research methods. Ankara: Nobel Publications.

Koç, Y. (2017a). A study on the relationship between high school students' physical education course sportsmanship behaviors and their patience levels. In M. Gammone, M. A. Icbay, \& H. Arslan (eds.), Recent Developments in Education (pp. 191-200). Bialystok: E-BWN. Available from http://iassr2.org/rs/005.pdf

Koç, Y. (2017b). Relationships between the Physical Education Course Sportsmanship Behaviors with Tendency to Violence and Empathetic Ability. Journal of Education and Learning, 6(3), 169-180. https://doi.org/10.5539/jel.v6n3p169

Koç, Y., \& Güllü, M. (2017). Research into sportspersonship behavior of high school students in physical education course in terms of some variables [In Turkish with English Abstract]. SPORMETRE, 15(1), 19-30.

Koç, Y., \& Tamer, K. (2016). A study on the sportsmanship behaviors of female students in physical education course according to different variables. Nigde University Journal of Physical Education and Sport Sciences, 7(1), 16-27. 
Koç, Y. (2013). Sportspersonship behavior scale in physical education course: Validity reliability study. Erzincan University Journal of Education Faculty, 15(1), 96-114.

Langdon, S. W. (2007). Conceptualization of respect: qualitative and quantitative evidence of four (five) themes, The Journal of Psychology, 141(5), 469-484. https://doi.org/10.3200/JRLP.141.5.469-484

Loomans, D., \& Loomans, J. (2005). Çocuklara öz saygıyı ve değerleri ögretmenin 100 yolu (Birinci Baskı), İzmir: Ege-Meta Yayınları.

Mc Cann, R., Dailey, R. M., Giles, H., \& Ota, H. (2005). Beliefs about intergenerational communication across the lifespan: Middle age and the roles of age stereotyping and respect norms. Communication Studies, 56, 293-311. https://doi.org/10.1080/10510970500319286

Miller, B. W., Roberts, G. C., \& Ommundsen, Y. (2004). Effect of motivational climate on sportspersonship among competitive youth male and female football players. Scandinavian Journal of Medicine \& Science in Sports, 14, 193-202. https://doi.org/10.1111/j.1600-0838.2003.00320.x

Shields, D. L., \& Bredemeier, B. J. L. (1995). Character development and physical activity. Champaign, IL: Human Kinetics.

Shields, D., La Voi, N., Bredemeier, B., \& Power, F. (2007). Predictors of poor sportspersonship in youth sports: Personal attitudes and social influences. Journal of Sport \& Exercise Psychology, 29(6), 747-762. https://doi.org/10.1123/jsep.29.6.747

Simon, B. (2007). Respect, equality, and power: A social psychological perspective. Gruppendynamik und Organisationsberatung, 38, 309-326. https://doi.org/10.1007/s11612-007-0027-2

Topan, A. (2011). Examination of the relationship between club experience and the understanding of fair play of secondary education students who participate in interscholastic soccer matches, (Unpublished master thesis). Gazi University, Ankara, Turkey.

Tsai, E., \& Fung, L. (2005). Sportspersonship in youth basketball and volleyball players. The Online Journal of Sport Psychology, 7(2), Retrieved April 17, 2013, from http://www. athleticinsight.com/Vol7Iss2/ Sportspersonship.htm

Türk, İ. (2009). Value education respect, (Unpublished master thesis). Gaziosmanpaşa University, Tokat, Turkey.

Tyler, T., \& Lind, A. (1992). A relational model of authority in groups. Advances in Experimental Social Psychology, 25, 115-191. https://doi.org/10.1016/S0065-2601(08)60283-X

Vallerand, R. J., Briere, N. M., Blanchard, C. M., \& Provencher, P. J. (1997). Development and validation of the multidimensional sportspersonship orientations scale. Journal of Sport \& Exercise Psychology, 19(2), 197-206. https://doi.org/10.1123/jsep.19.2.197

Yazıc1, A., \& Yazıcı, S. (2015). Study on the reliability and validity of the respect scale. International Periodical for the Languages, Literature and History of Turkish or Turkic, 10(4), 769-780. Retrieved 4 January 2016 from https://doi.org/10.7827/TurkishStudies.9079

Yıldıran, İ. (2005). Fair play eğitiminde beden eğitiminin rolü. Gazi Beden Eğitimi ve Spor Bilimleri Dergisi, 5(1), 316.

\section{Notes}

Note 1. This study was presented at the DAKAM's Education Studies '17 / International Conference on Education and Learning, (April 21, 2017), İstanbul /Turkey.

\section{Copyrights}

Copyright for this article is retained by the author(s), with first publication rights granted to the journal.

This is an open-access article distributed under the terms and conditions of the Creative Commons Attribution license which permits unrestricted use, distribution, and reproduction in any medium, provided the original work is properly cited. 